Review

\title{
Targeting human telomerase for cancer therapeutics
}

\author{
Lionel Guittat ${ }^{1}$, Patrizia Alberti ${ }^{1}$, Dennis Gomez ${ }^{2}$, Anne De Cian ${ }^{1}$, Gaëlle Pennarun ${ }^{1,3}$, \\ Thibault Lemarteleur ${ }^{2}$, Chafke Belmokhtar ${ }^{4}$, Rajaa Paterski', Hamid Morjani', \\ Chantal Trentesaux ${ }^{2}$, Eliane Mandine ${ }^{4}$, François Boussin ${ }^{3}$, Patrick Mailliet ${ }^{4}$, \\ Laurent Lacroix ${ }^{1}$, Jean-François Riou ${ }^{2}$ and Jean-Louis Mergny ${ }^{1, *}$ \\ ${ }^{1}$ Laboratoire de Biophysique, Muséum National d'Histoire Naturelle USM503, INSERM U 565, CNRS \\ UMR 5153, 43, rue Cuvier, 75231 Paris cedex 05, France; ${ }^{2}$ Laboratoire d'Onco-Pharmacologie, JE 2428, \\ UFR de Pharmacie, Université de Reims Champagne-Ardenne, 51096 Reims, France; ${ }^{3}$ Laboratoire de Ra- \\ diopathologie, CEA, 92265 Fontenay aux Roses, France; ${ }^{4}$ Aventis Pharma SA, Centre de Recherche de Paris, \\ Quai Jules Guesde, 94403 Vitry sur Seine, France; *Author for correspondence (e-mail: mergny@vnu- \\ mail.com; phone: +33-1-40-79-36-89; fax: + 33-1-40-79-37-05)
}

Received 4 May 2004; accepted in revised form 21 September 2004

Key words: Apoptosis, Cancer, G-quadruplex ligands, G-quartets, Senescence, Telomerase, Telomere

\begin{abstract}
The enzyme telomerase is involved in the replication of telomeres, specialized structures that cap and protect the ends of chromosomes. Its activity is required for maintenance of telomeres and for unlimited lifespan, a hallmark of cancer cells. Telomerase is overexpressed in the vast majority of human cancer cells and therefore represents an attractive target for therapy. Several approaches have been developed to inhibit this enzyme through the targeting of its RNA or catalytic components as well as its DNA substrate, the single-stranded 3'-telomeric overhang. Telomerase inhibitors are chemically diverse and include modified oligonucleotides as well as small diffusable molecules, both natural and synthetic. This review presents an update of recent investigations pertaining to these agents and discusses their biological properties in the context of the initial paradigm that the exposure of cancer cells to these agents should lead to progressive telomere shortening followed by a delayed growth arrest response.
\end{abstract}

Abbreviations: 2'MOE - 2'-O-(2-methoxyethyl) RNA; 2'OMe - 2'-O-methyl-RNA; hTERT - human Telomerase Reverse Transcriptase; hTR - human Telomerase RNA; LNA - locked nucleic acids; PN phosphoramidate; PNA - peptide nucleic acids; PS - phosphorothioate; TRAP - Telomeric Repeat Amplification Protocol.

\section{Introduction}

Telomeric DNA consists of highly repetitive but short sequences characterized by an asymmetry of guanines and cytosines, which are generally placed on two separate strands. In most organisms, these repetitions are regular (except in some lower eukaryotes) and of variable length; the telomeric motif can spread over tens of kilobases. Human telomeric sequences are synthesized by telomerase, a specialized reverse transcriptase. Telomerase is composed of a catalytic subunit (hTERT) and a 
451 nucleotide RNA (hTR) that carries the template for the addition of the repetitive motif $\mathrm{d}(\mathrm{GGTTAG})_{n}$ to the $3^{\prime}$ end of chromosomes. Telomerase was first identified in ciliates (Greider and Blackburn 1985).

This enzyme telomerase is essential for immortalization and tumorigenicity (Meyerson et al. 1997; Hahn et al. 1999a). It is inactive (or less active) in normal somatic cells as compared to cancer cells. Normal human cells transfected with vectors encoding the human telomerase catalytic subunit become immortal (Bodnar et al. 1998). Unlimited proliferative potential, which depends on telomere maintenance, is one of six properties considered hallmarks of cancer cells (Hanahan and Weinberg 2000). Key studies have since confirmed the value of telomerase as a potential target for anticancer therapy: expression of a dominant negative mutant of hTERT in tumor cells results in the inhibition of telomerase activity, reduction in telomere length, as well as delayed cell death and abrogation of tumorigenicity in vivo (Hahn et al. 1999b). These observations demonstrate that disruption of telomere maintenance limits the lifespan and tumorigenicity of human cancer cells, thus validating telomerase as a target for the development of anti-neoplastic therapies. Compounds targeting its reverse transcriptase activity, its RNA component or its DNA substrate have since been reported. Several reviews on telomerase inhibitors have been published within the last few years (Kerwin 2000; White et al. 2001; Mergny et al. 2002; Cuesta et al. 2003; Rezler et al. 2003; Saretzki 2003). For this reason, this review will mainly be focused on the recent developments in the field.

\section{The TRAP telomerase assay}

The evaluation of telomerase inhibitors was made possible by the introduction of enzymatic assays to measure the activity of telomerase in cell extracts. A so-called 'direct' telomerase assay was first developed, which was relatively insensitive for detecting the limiting amount of telomerase activity present in cell extracts. A PCR-based assay, the Telomeric Repeat Amplification Protocol (TRAP), was subsequently developed to overcome this limitation (Kim et al. 1994). In the TRAP assay, a PCR reaction is utilized to amplify the products of the telomerase reaction, thereby increasing the sensitivity of the assay. Performing the TRAP assay in the presence of increasing concentrations of a potential telomerase inhibitor can be used to determine the inhibitor's $\mathrm{IC}_{50}$. To discriminate between the inhibition of telomerase or of the Taq polymerase, an internal control (ITAS) is included, which is designed to co-amplify with the telomerase products. For samples containing Taq inhibitors, procedures have been developed to remove these inhibitors after telomerase extension and before PCR amplification (Francis and Friedman 2003). It should also be noted that nanosensors have recently been developed for the sensitive detection of telomerase activity (Grimm et al. 2004).

\section{Oligonucleotidic inhibitors}

\section{Targeting $h T R$}

The RNA component of telomerase hTR is absolutely required for telomerase reverse transcription and is therefore a natural target for anti-telomerase agents. Unlike hTERT, hTR is present in most normal tissues that do not express telomerase activity. Thus, the targeting of hTR in normal human somatic cells is not expected to generate toxicity, as these cells are mostly telomerase-negative. However, the recent observation that a low but detectable telomerase activity is present in cycling primary presenescent human fibroblasts, which were previously thought to lack hTERT expression and telomerase activity, challenges this prediction (Masutomi et al. 2003). Different strategies and chemical modifications (Figure 1) have successfully been developed to target hTR, starting with antisense oligomers. hTR has several features that makes it a good target for oligonucleotidic inhibitors: (i) hTR is not translated and should remain unprotected by ribosomal machinery, so that RNAse $\mathrm{H}$-independent strategies for targeting hTR should be possible; (ii) hTR provides a template (nucleotide 46-56; 5'-CUAACCCUAAC- $3^{\prime}$ ) for reverse transcription that is expected to be highly accessible.

$2^{\prime}$ - $O$-methyl-RNA (2'-O-MeRNA) and 2'-O- (2methoxyethyl) (2'-MOE) RNAs directed against the template region of hTR possess favorable pharmacokinetic properties and inhibit human telomerase with $\mathrm{IC}_{50}$ values of $2-10 \mathrm{nM}$ (Pitts and 

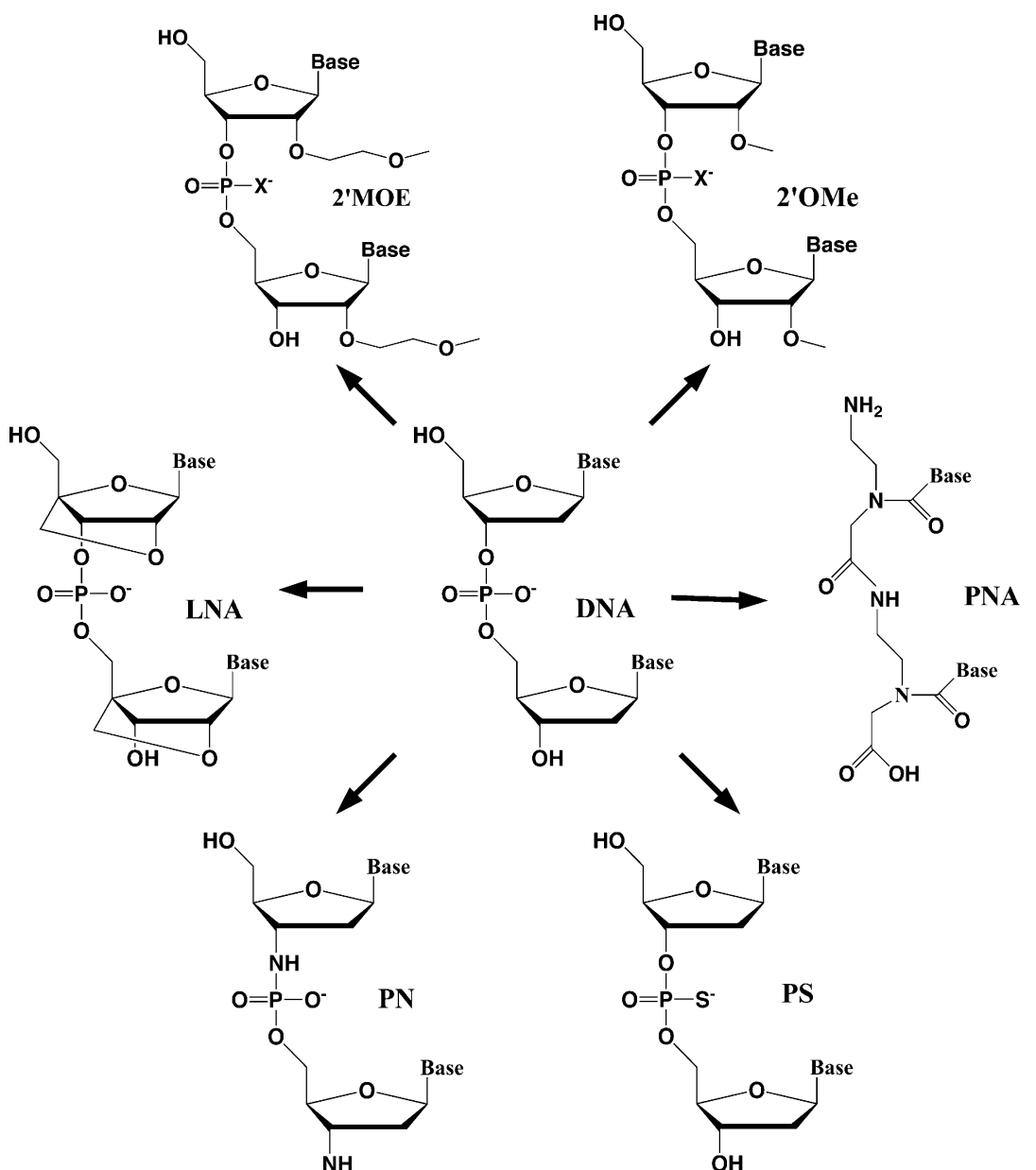

Figure 1. Modified oligonucleotides used for telomerase inhibition. 2'MOE: 2'-O-(2-methoxyethyl) RNA; 2'OMe: 2'-O-methyl-RNA; PNA: peptide nucleic acids; LNA: locked nucleic acids; PN: phosphoramidate; PS: phosphorothioate.

Corey 1998; Elayadi et al. 2001; Figure 1). Longterm treatment with $2^{\prime}$-MOE oligomers induces telomere shortening in human prostate cancer cells (Chen et al. 2003). 2',5'-oligoadenylate antisense oligomers directed against hTR have been described that could efficiently inhibit telomerase (Kondo et al. 1998) as well as the growth of xenografted tumors (Mukai et al. 2000; Koga et al. 2001). A $2^{\prime}, 5^{\prime}$-oligoadenylate oligomer directed hTR inhibited telomerase activity in cervical cancer cells, rapidly decreased cell viability and induced apoptosis within 3-6 days of treatment, when telomeres had not yet shortened (Yatabe et al. 2002).

Peptide nucleic acids (PNAs) are neutral oligonucleotide analogues made of a flexible polyamide backbone. PNAs directed against the template region of hTR were among the first oligomers tested that could efficiently inhibit telomerase (Norton et al. 1996). Using a scanning approach, the binding determinants within hTR that are needed for the potent inhibition of telomerase by PNAs have been delineated (Hamilton et al. 1997). Covalent linkage of PNAs to a small peptide containing five arginines was found to improve telomerase inhibition (Harrison et al. 1999a) and facilitated nuclear import (Villa et al. 2000). Electroporation of these agents effectively inhibits telomerase activity in intact cells, shortens telomeres, reduces colony size, and arrests cell proliferation after a lag period of 5-30 cell generations, consistent with suppression of their 'immortality' (Shammas et al. 1999).

LNAs (bicyclic analogues) directed against the template region of hTR exhibit high affinity and 
inhibit telomerase $\left(\mathrm{IC}_{50}=2 \mathrm{nM}\right)$ with limited nonspecific cellular toxicity (Elayadi et al. 2002). Phosphoramidates and thiophosphoramidates analogues are other promising telomerase inhibitors $\left(\mathrm{IC}_{50}=1 \mathrm{nM}\right)$ that can induce delayed senescence and telomere shortening (Pruzan et al. 2002). Two such oligomers called GRN163 and GRN163L were tested in vivo against a large panel of xenografted tumors. They exhibited strong antitumor activities on prostate, lymphoma and myeloma models with short telomeres (Akiyama et al. 2003; Asai et al. 2003; Wang et al. 2004).

Yokoyama et al. (1998) as well as Folini et al. (2000) generated hammerhead ribozymes composed of a catalytic domain with flanking sequences complementary to hTR. When the ribozyme was delivered to growing melanoma or carcinoma cells, a marked inhibition of telomerase activity was observed. The ribozyme-transfected melanoma cells had significantly longer doubling times than the control cells, and displayed a dendritic appearance in monolayer culture, which was not associated with telomere shortening (Folini et al. 2000). Yokoyama et al. (2002) recently designed a divalent ribozyme to cleave hTR at two positions. Compared to its monovalent counterpart, this divalent ribozyme cleaved hTR more efficiently in vitro, but its capacity to inhibit telomerase in carcinoma cells was reduced. Other alternative approaches were also tested and found to inhibit telomerase, which included short duplex RNAs (short-interfering RNA or siRNA) targeting hTR (Kosciolek et al. 2003) and hTR-hybridizing oligonucleotides that inhibited telomerase by blocking the association of hTERT with hTR (Keppler and Jarstfer 2004).

\section{Targeting hTERT}

A limited number of studies have been performed with antisense oligomers against the catalytic component of telomerase. Phosphorothioate oligonucleotides against the hTERT mRNA were tested in DU145 prostate cancer cells. A significant delayed inhibition of cell viability occurred (Schindler et al. 2001; Kraemer et al. 2003). A $235 \mathrm{bp}$ fragment of the hTERT cDNA was subcloned, and sense and antisense hTERT expression vectors were transfected into a human thyroid carcinoma cell line. Significant down-regulation of telomerase activity and delayed (20 PD) cell growth inhibition and apoptosis were seen in cells transfected with the antisense construct. Moreover, anchorage-independent growth in vitro and tumor growth rate in vivo were both diminished in the antisense hTERT clones (Teng et al. 2003). In a separate study, photochemical internalization of anti-hTERT PNAs into the cytoplasm of DU145 prostate cancer cells led to a marked inhibition of telomerase activity and reduced cell survival (Folini et al. 2003).

Yokoyama et al. (2000) studied the efficiency of several hammerhead ribozymes targeting the hTERT mRNA by transient and stable transfection procedures. The ribozyme targeting 13 nucleotides downstream from the $5^{\prime}$-end of the hTERT mRNA (13-ribozyme) exhibited the strongest telomerase inhibitory activity. In an independent study, telomerase-positive ovarian cancer cell lines with widely differing telomere lengths were efficiently transduced with an adenovirus expressing a ribozyme directed against the conserved T motif of hTERT. Three days after transduction, telomerase activity was significantly reduced and massive cell loss was induced in cultures of all four cell lines tested (Saretzki et al. 2001).

siRNAs were also generated against the hTERT mRNA. In a recent study, Masutomi et al. (2003) demonstrated that the rate-limiting hTERT subunit is also expressed in normal cycling primary human fibroblasts, which were previously thought to lack hTERT expression and telomerase activity. Disruption of telomerase activity by siRNA slows cell proliferation, restricts cell lifespan, and alters the maintenance of the $3^{\prime}$ single-stranded telomeric overhangs without altering the overall rate of telomere shortening.

\section{Catalytic inhibitors}

\section{Nucleoside analogues}

Nucleoside analogues acting as chain-terminating inhibitors of reverse transcriptases were among the first drugs to be tested for their ability to inhibit telomerase (Strahl and Blackburn 1994; Figure 2). Both Ara-GTP and ddGTP efficiently inhibited telomerase activity in vitro. In their nucleoside form, the analogues azidothymidine 

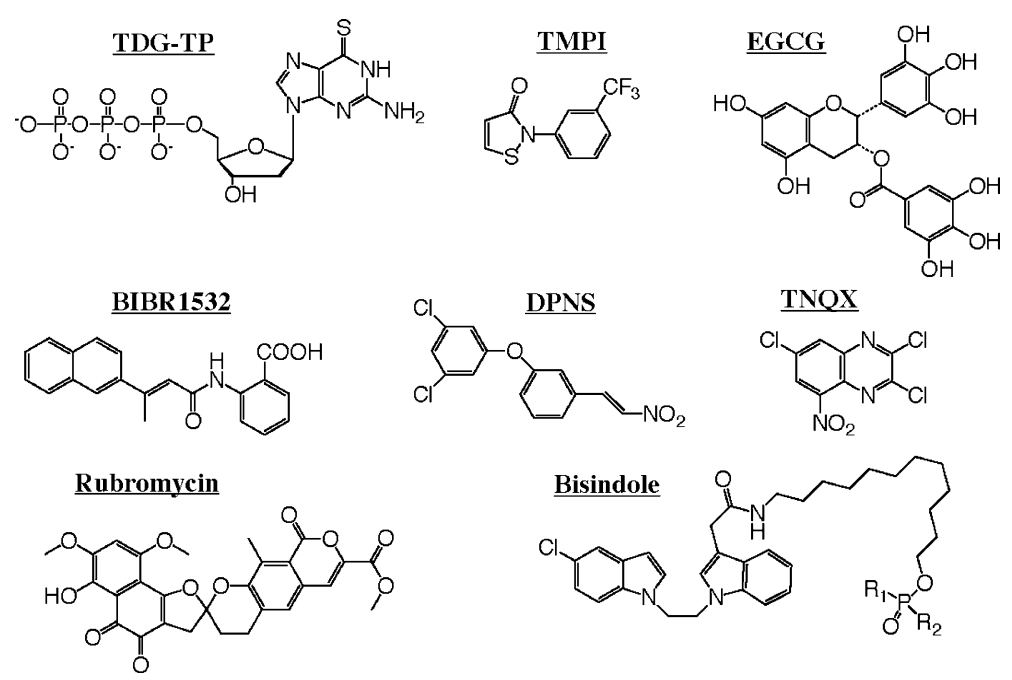

Figure 2. Chemical formula of telomerase inhibitors. The chemical structures of a nucleoside inhibitor of telomerase (6-thio-2'deoxyguanosine $5^{\prime}$-triphosphate (TDG-TP)) and of many non-nucleoside inhibitors of the enzyme (epigallocatechin gallate (EGCG), BIBR1532, 3-(3,5-dichlorophenoxy)-nitrostyrene (DPNS), 2,3,7-trichloro-5-nitroquinoxaline (TNQX), isothiazolone derivatives (e.g. TMPI), bisindole and rubromycin derivatives) are shown.

(AZT), 3'-deoxy-2', 3'-didehydrothymidine (d4T) and Ara-G caused consistent and rapid telomere shortening in vegetatively growing tetrahymena. The same group analyzed the effects of such molecules in two immortalized human cell lines (Strahl and Blackburn 1996). Dideoxyguanosine (ddG) caused reproducible, progressive telomere shortening over several weeks of passaging, after which point telomeres became stable but remained short. AZT caused progressive telomere shortening in some but not all $\mathrm{T}$ - and B-cell cultures (Strahl and Blackburn 1996) as well as MCF7 (Multani et al. 1998), HeLa (Gomez et al. 1998) and mouse fibroblasts cells (Yegorov et al. 1996). When tested in combination with 5-fluorouracil (5-FU), the presence of AZT increased 5-FU cytotoxicity, suggesting that the effects of these two drugs are synergistic (Brown et al. 2003). A very potent and specific nucleoside telomerase inhibitor, 6-thio-2'-deoxyguanosine $5^{\prime}$-triphosphate $\left(\mathrm{TDG}-\mathrm{TP} ; \mathrm{IC}_{50}=0.06 \mu \mathrm{M}\right)$, has also been described (Fletcher et al. 2001).

\section{Non-nucleoside inhibitors}

A variety of non-nucleoside drugs have also been shown to inhibit telomerase (Figure 2). Green tea appears to contain epicatechin derivatives, such as epigallocatechin gallate (EGCG), which strongly and directly inhibit telomerase (Naasani et al. 1998). In the presence of nontoxic concentrations of EGCG, two representative human cancer cell lines, U937 monoblastoid leukemia cells and HT29 colon adenocarcinoma cells, showed lifespan limitations accompanied with telomere shortening, chromosomal abnormalities, and expression of senescence-associated $\beta$-galactosidase activity. According to Naasani et al. (2003), EGCG would be acting as a prodrug-like molecule, which needs to undergo structural changes for potent inhibitory activity against telomerase (Naasani et al. 2003). In a recent study, EGCG inhibited telomerase and triggered apoptosis in a number of cervical cancer cell lines, and prevented progression in an organotypic model of cervical cancer (Yokoyama et al. 2004). In the micromolar range, EGCG is also active on telomerase-positive primitive neuroectodermal tumor cell lines (Didiano et al. 2004). For the inhibition of telomerase in leukemia U937 cells, one synthetic derivative of EGCG was recently found to be 15 - to 20 -fold more potent than EGCG (Seimiya et al. 2002).

With an $\mathrm{IC}_{50}$ of $93 \mathrm{nM}$, BIBR 1532 is one of the most potent non-nucleoside inhibitors of telomerase (Damm et al. 2001). BIBR1532 is a mixed-type non-competitive inhibitor (Pascolo et al. 2002). With no evidence of acute cytotoxicity, treatment 
of cancer cells with this compound led to progressive telomere shortening and, after a characteristic lag, to a proliferation block displaying hallmarks of senescence, which included morphological and proliferative changes, chromosomal aberrations, and altered patterns of gene expression (Damm et al. 2001). In a mouse xenograft model, pretreatment of tumor cells with this inhibitor led to telomerase inhibition, telomere shortening, and to a marked reduction in tumorigenic potential. It should be noted, however, that the $\mathrm{IC}_{50}$ of BIBR 1532 have recently been reported to be considerably higher ( $\mu \mathrm{M}$ range) in cell extracts than those previously reported with purified telomerase (Barma et al. 2003).

The screening of chemical libraries allowed the identification of various molecules as potent inhibitors of telomerase. One of these compounds, 3-(3,5-dichlorophenoxy)-nitrostyrene (DPNS), is a mixed-type noncompetitive inhibitor $\left(\mathrm{IC}_{50}<\right.$ $1 \mu \mathrm{M}$; Kim et al. 2003b). Extensive propagation of cancer cells in the presence of DPNS resulted in progressive telomere erosion followed by the induction of a senescence phenotype. The same group also reported 2,3,7-trichloro-5-nitroquinoxaline (TNQX) as a potent and specific inhibitor of telomerase, of the noncompetitive mixed type $\left(\mathrm{IC}_{50}=1.4 \mu \mathrm{M}\right.$; Kim et al. 2003a). Long-term cultivation of breast cancer cell line MCF7 with a TNQX concentration that did not cause acute cytotoxicity resulted in progressive telomere attrition followed by an increased incidence of chromosome abnormalities as well as the induction of a senescence phenotype. An independent screen led to the identification of isothiazolone derivatives $\left(\mathrm{IC}_{50}=1 \mu \mathrm{M}\right.$ for TMPI; Hayakawa et al. 1999). Inhibition of telomerase by TMPI was quenched by dithiothreitol or glutathione, suggesting that these inhibitors act on a cysteine residue. Finally, bisindole derivatives with $\mathrm{IC}_{50}$ values in the submicromolar range were also described (Sasaki et al. 2001).

\section{Telomere-interacting drugs}

\section{G-quartets ligands}

The 3 '-telomeric overhang found at the end of all telomeres can form a unique structure termed a Gquadruplex. A unique feature of G-quadruplexes is the association of four DNA strands held together by the hydrophobic stacking of large, planar and hydrogen-bonded G-quartets coordinated by a monovalent cation (Williamson et al. 1989; Figure 3A). A G-quartet (alternatively termed Gtetrad) involves four guanines. Self-association is favored by self-complementary hydrogen bond donors and acceptors present on both sides of the base, leading to the formation of a cyclic arrangement held by eight hydrogen bonds per quartet. The presence of a central cation helps maintain the stability of the structure. However, not all cations are equivalent for G-quadruplex stabilization; their stabilizing capabilities being ranked as followed: $\mathrm{K}^{+}>\mathrm{Rb}^{+}>\mathrm{Na}^{+}>\mathrm{Cs}^{+}$ $>\mathrm{Li}^{+}$. Cation size and hydration energy might explain these differences (Hud et al. 1996). It is interesting to note that potassium, which is very abundant in the intracellular medium, is highly favorable to G-quadruplex formation.

A G-quadruplex consists of at least two layers of G-quartets. The distance between two consecutive G-quartets is similar to the distance between two base pairs in a B-duplex $(3.3 \AA)$. Different Gquadruplex structures exist, depending on the orientation of the DNA strands and the syn/anti conformation of the guanines (Williamson 1994). Despite relying on a single building block (the Gquartet), G-quadruplexes are highly polymorphic and can give rise to a large number of different structures. For example, a human telomeric DNA strand carrying four blocks of consecutive guanines may fold into at least two different intramolecular G-quadruplexes structures, each consisting of three adjacent G-quartets (Wang and Patel 1993; Parkinson et al. 2002; Figure 3a). These intramolecular telomeric G-quadruplexes are fairly stable under physiological conditions. Thanks to the presence of a $3^{\prime}$ terminal G-rich telomeric overhang, telomeric quadruplex formation does not necessitate the separation of the two strands of duplex DNA, which would otherwise be energetically unfavorable (Phan and Mergny 2002) with the exception of specific circumstances ( $\mathrm{Li}$ et al. 2003; Miyoshi et al. 2004).

Optimal telomerase activity requires an unfolded single-stranded substrate, such that G-quadruplex formation directly inhibits telomerase elongation in vitro (Zahler et al. 1991). Therefore, ligands that selectively bind and stabilize G-quadruplex structures may inhibit 

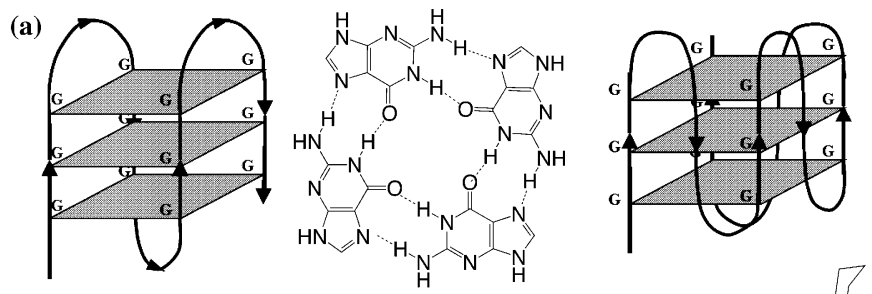

(b) disubstituted amidofluorenone

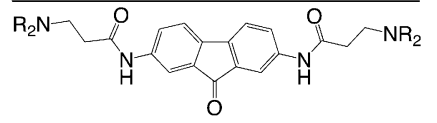

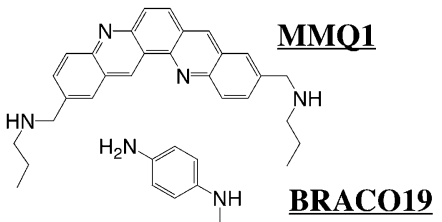

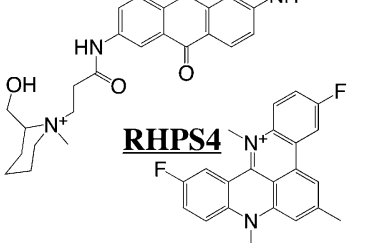<smiles>O=C(CCN1CCCC1)NC1C=NC2CC(NC(=O)CCN3CCCC3)CCC2CC1</smiles>

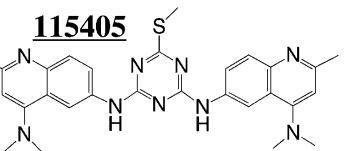<smiles>Cc1cc(NC2CCC3C4CCC(N)CC4C(c4ccccc4)N(C)C3C2)nn1C</smiles>

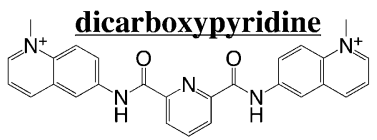

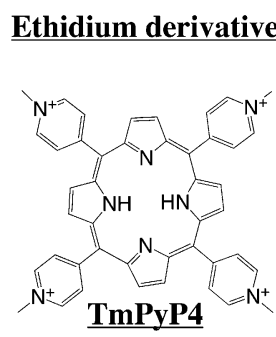

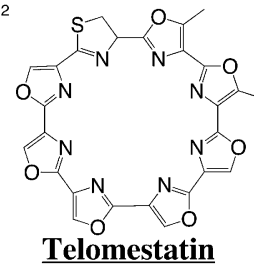

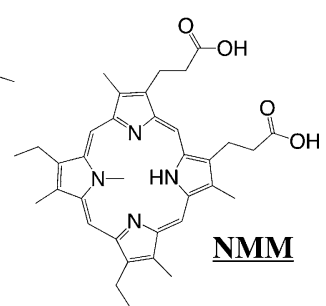

Figure 3. Structure of a G-quadruplex, and chemical formula of telomere-interfering agents. (a) Structure of a quartet involving four coplanar guanines (center) and two possible conformations of the intramolecular G-quadruplexes formed by human telomeric DNA (left and right). (b) Chemical formula of some G-quadruplex ligands.

telomerase activity. In recent years, many such ligands have been identified through diverse biochemical and biophysical methods, including the TRAP or TRAP-G4 assay (Kim et al. 1994; Kim and Wu 1997; Gomez et al. 2002), Taq polymerase stop assay (Han et al. 1999), and fluorescence melting experiments (Mergny et al. 2001; Darby et al. 2002; Guyen et al. 2004). Overall, a good correlation was found between G-quadruplex stabilization and telomerase inhibition among hundreds of derivatives tested so far.

The number of G-quadruplex ligands has grown rapidly over recent years, resulting in a range of molecules that inhibit telomerase through their direct contact with its substrate, the 3'-telomeric overhang (Sun et al. 1997; Fedoroff et al. 1998; Wheelhouse et al. 1998; Harrison et al. 1999b; Perry et al. 1999; Caprio et al. 2000; Neidle et al. 2000; Gowan et al. 2001, 2002; Koeppel et al. 2001; Mergny et al. 2001; Read et al. 2001; Shi et al. 2001; Alberti et al. 2002b; Heald et al. 2002; Kim et al. 2002; Rossetti et al. 2002; Harrison et al. 2003; Maraval et al. 2003; Guyen et al. 2004). For some of these ligands, combinatorial chemistry could successfully be employed as a mean of improving their telomerase inhibitory potential (Schouten et al. 2003; Whitney et al. 2004). Examples of G-quadruplex ligands are shown in Figure 3b. The discovery of these new ligands is of the utmost importance for 
the more comprehensive understanding of the biological role of G-quadruplexes and for the design of new drugs with enhanced telomerase inhibitory activity and reduced toxicity. Features shared by these ligands include a large flat aromatic surface, presence of cationic charges, and ability to adopt a terminal stacking mode. The surface of a G-quartet is much larger than that displayed by a base pair, explaining in part how a large aromatic molecule may have a preference for G-quadruplex because of favorable stacking interactions. In most cases, distinct binding sites are available for external stacking at both ends of a G-quadruplex. This does not necessarily implies that a maximum of two drug molecules are bound per G-quadruplex, as several drugs may stack on the same G-quartet. Daunomycin, for example, binds G-quadruplexes as a trimer (Clark et al. 2003). Some compounds may suffer from insufficient preference of G-quadruplexes over duplex DNA (Alberti et al. 2002a). Currently, telomestatin (see Figure 3b) may be considered as one of the most potent and selective G-quadruplex ligands described so far since its quadruplexstabilizing activities can resist up to a 3000 -fold molar excess of duplex DNA (Gomez et al. 2004b and Guittat et al. unpublished observations).

Until recently, few structural data were available on the mode of interaction of these molecules with G-quadruplex DNA. An NMR-based model of the drug PIPER bound to a parallel G-quadruplex was published in 1998 (Fedoroff et al. 1998). A complex between an amidoanthraquinone ligand and a parallel G-quadruplex formed by TGGGGT repeats was reported in 2000 (Read and Neidle 2000). Fortunately, several high-resolution crystal and NMR structures of G-quadruplex ligands have recently been published (Gavathiotis et al. 2001, 2003; Clark et al. 2003; Cocco et al. 2003; Haider et al. 2003). With the possible - and controversial - exception of a cationic porphyrin (Haq et al. 1999), all ligands interact with G-quadruplexes by external stacking of a terminal G-quartet. Telomeric G-quadruplex DNA structure polymorphism (Parkinson et al. 2002; Neidle and Parkinson 2003; Phan and Patel 2003) also leads to uncertainties in the rational design of compounds that target these G-quadruplexes, making the rational design of these telomere-specific drugs more difficult. Few molecules actually distinguish between the various classes of
G-quadruplexes (intra- or inter-molecular, parallel or antiparallel). In order to achieve specific telomerase inhibition, it might be interesting to identify compounds that would only interact with the telomeric G-quadruplexes (Alberti et al. 2003). As none of the current ligands fulfill this condition, nonspecific and undesired cellular effects are expected to occur.

\section{Other types of telomere ligands}

Minor groove binders may also be used to target double-stranded telomeric repeats (Maeshima et al. 2001). A hairpin polyamide-cyclopropanepyrroloindole (CPI) conjugate alkylates its target adenine in the telomere repeats, $5^{\prime}$-CCCTAA- $3^{\prime}$, and inhibits the growth of a variety of cancer cell lines (Takahashi et al. 2003). The anti-cancer drug cisplatin, aside from its possible recognition of G-quadruplexes (see above), may also recognize duplex telomeric DNA, as these long tandem repeats are potential targets for cisplatin and other platinum compounds. Telomeres in cisplatin-treated HeLa cells are markedly shortened and degraded (Ishibashi and Lippard 1998). In contrast, long-term cultivation of colorectal carcinoma cells with cisplatin or 5-FU select for cells that display drug resistance and telomere elongation (Kuranaga et al. 2001). Platinum derivatives, including 2,3-dibromosuccinato [2-(methylaminomethyl)pyridine]platinum (II) (Furuta et al. 2003) or cis-dichloropyridine5-isoquinolinesulfonic acid $\mathrm{Pt}(\mathrm{II})$ (Colangelo et al. 2003), have been found to represent strong telomerase inhibitors, with $\mathrm{IC}_{50}$ in the $\mu \mathrm{M}$ range.

Shammas et al. (2004) described PNAs designed to hybridize and target to the G-rich 3 '-telomeric overhang that caps the ends of telomeres. In transformed human fibroblasts, these PNA oligomers did not inhibit telomerase activity in vitro but elicited cell death by apoptosis and caused significant reductions in colony size. Combining these anti-telomere PNAs with anti-hTR PNAs capable of inhibiting telomerase resulted in marked reductions of telomere length, induction of apoptosis, and a near-complete inhibition of colony growth. These effects were greater than those evoked by either agent alone (Shammas et al. 2004). 


\section{Anti-telomere vs. anti-telomerase agents}

There are fundamental differences between the targeting of telomeres and the targeting of the telomerase subunits (hTR, hTERT or associated factors). According to the initial paradigm, antitelomerase agents should lead to progressive telomere shortening without evidence of acute toxicity, and should only decrease proliferation once telomeres have reached a critically short length (Herbert et al. 1999; Shammas et al. 1999; Damm et al. 2001). This paradigm has been verified by several key experiments that were intended for target validation purposes (Damm et al. 2001). Anti-telomere agents, on the other hand, could potentially kill cancer cells after short-term exposure and without delays, but may also have detrimental effects on normal telomerase-negative cells. Indeed, telomeres exist in the absence of telomerase activity and play a fundamental role in telomerase-negative cells: the capping and protection of chromosome ends. Thus, agents that stabilize telomeric G-quadruplexes could not only inhibit telomerase, but may also alter telomere function and produce short-term toxicity in both normal and cancer cells. However, differences in telomere capping between normal and cancer cells (causing genomic instability and telomere alterations in cancer cells) could provide telomere-disrupting agents with a therapeutic index and support their clinical use for the treatment of cancer patients.

\section{Long- vs. short-term toxicity of G-quadruplex ligands}

Depending on the agent, the exposure of cancer cells to G-quadruplex ligands can produce a response that can either be immediate (short-term toxicity) or delayed (long-term toxicity). In lymphomas and myelomas, the highly potent telomerase inhibitor telomestatin $\left(\mathrm{IC}_{50}=5 \mathrm{nM}\right)$ induced a shortening of the telomeres that preceded a delayed wave of apoptosis (Nakajima et al. 2003; Shammas et al. 2003). Delays were also noted in the apoptotic response induced by telomestatin in leukemia cell lines (Tauchi et al. 2003). Similarly, the long-term exposure of lung adenocarcinoma cells (A549) to G-quadruplex ligands of the triazine series (Riou et al. 2002) led to delayed growth arrest response, which was associated with the appearance of a senescent-like phenotype (large and flat morphology; expression of senescence-associated $\beta$-galactosidase activity). However, G-quadruplex ligands can also trigger an immediate response in the absence of telomere shortening. Thus, subtoxic concentrations of the acridine G-quadruplex ligands RHPS4 or BRACO19 could trigger growth arrest in tumor cells after just 15 days of exposure, before any detectable telomere shortening (Gowan et al. 2001, 2002). Likewise, the cationic porphyrin TmPyP4 could induce growth arrest in ALT cells (Kim et al. 2003c) and promote the incidence of anaphase bridges in sea-urchin embryos (Izbicka et al. 1999). Short- and/or long-term antiproliferative effects on ALT cells have also been observed with other G-quadruplex ligands, such as RHPS4 and 12459. Although telomestatin seems to remain specific to telomerase-positive cells (Riou et al. 2002; Kim et al. 2003c; Shammas et al. 2003), these results suggest that the direct target of most of these ligands is the telomere rather than telomerase.

Increasing evidence indicates that the capping of the single-stranded $3^{\prime}$-telomeric overhang might be important in controlling senescence (Karlseder et al. 2002; Stewart et al. 2003). Therefore, the hypothesis that these ligands provoke uncapping of the telomeric overhang has emerged but needs to be experimentally validated. Our group now generated evidence that G-quadruplex ligands, including telomestatin and 2,6 pyridine-dicarboxylate derivatives, can efficiently impair the single-stranded conformation of the 3'-telomeric G-rich overhang (Figure 4). Telomestatin and the $3^{\prime}$-telomeric overhangs can form strong and specific interactions that are compatible with the formation of stable G-quadruplexes. Moreover, prolonged treatment of tumor cells with telomestatin results in marked decreases in the amount of G-rich overhangs that correlate with the onset of senescence, thus suggesting that the actual target of the biological action of this molecule might in fact be the 3'-telomeric G-rich overhang (Gomez et al. 2004b). A recent report indicates that TRF2 is required to protect the 3 '-telomeric overhangs from the action of the excision repair nuclease ERCC1/XPF, which participates in overhang removal (Zhu et al. 2003). The alteration of the conformation of the 3'-telomeric overhangs by G-quadruplex ligands is therefore proposed to 

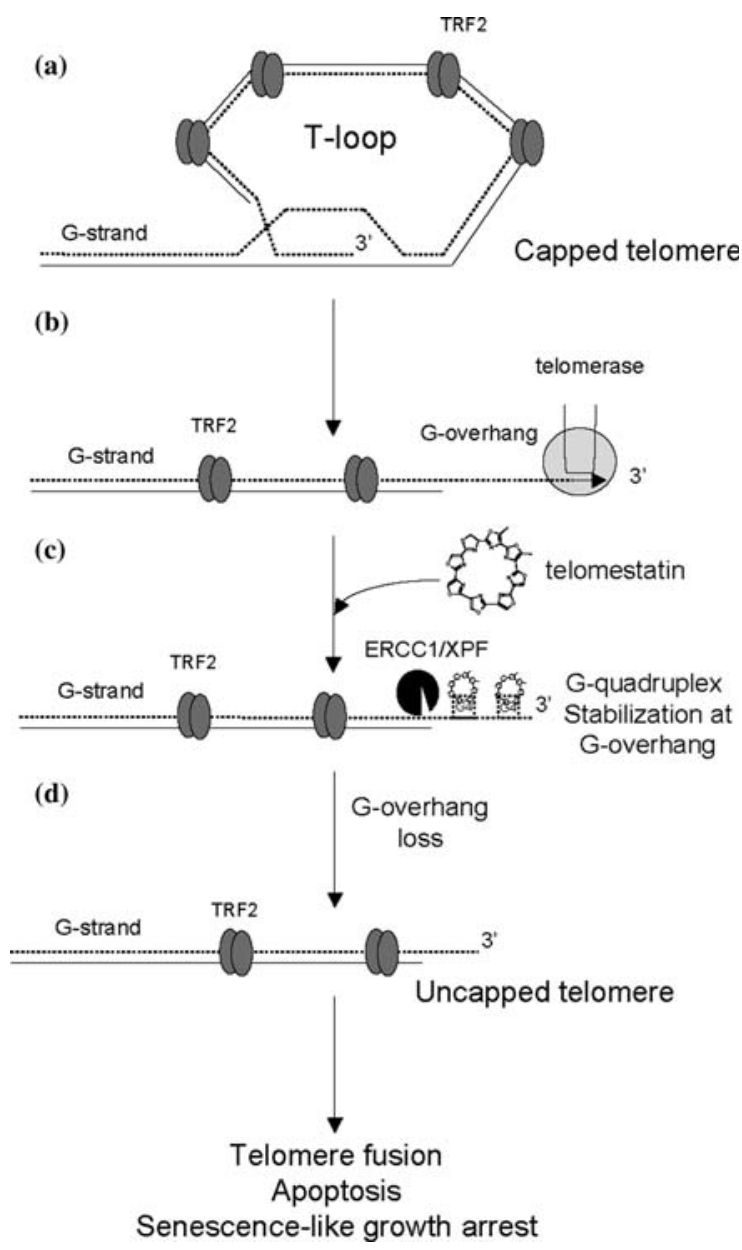

Figure 4. Model for the action of a G-quadruplex ligand at the 3 '-telomeric single-stranded overhang. Interaction of telomestatin with the 3 '-telomeric single-stranded overhang (G-overhang) impairs the formation of the T-loop and results in the ERCC1/XPF-mediated degradation of the G-rich overhang leading to the formation of an uncapped telomere. (a) Capped telomere forming a T-loop before DNA replication. (b) During replication, the T-loop structure is unfolded and telomerase extends the overhang. (c) The addition of telomestatin blocks telomerase activity and modifies the single-stranded conformation of the G-rich overhang, promoting the formation of Gquadruplexes onto the overhang. This modification results in a failure to reform the T-loop following DNA replication, leading to the exposure of the $3^{\prime}$-telomeric G-rich overhang and its possible cleavage by the endonucleolytic activity of ERCC1/ XPF. (d) Loss of the G-rich overhang results in an uncapped telomere structure that leads to telomere fusions and to either senescence or apoptosis depending on cell background.

alter the capping of telomeres by essential factors, such as TRF2, thus provoking the immediate removal of the 3 -telomeric overhangs followed by subsequent cell cycle arrest or apoptosis.

\section{Resistance to G-quadruplex ligands}

Recent experiments have demonstrated that it is possible to select cancer cells that can resist shortor long-term exposure to a G-quadruplex ligand, the triazine derivative 12459 (Gomez et al. 2003a, b, 2004a). In selected clones, resistance was associated with increased telomerase activity, increased telomere length, overexpression of hTERT, and alteration in the splicing pattern of hTERT (Gomez et al. 2003b). Resistance to long-term exposure was unrelated to the classical resistance mechanisms, such as the involvement of the $\mathrm{ABC}$ transporters. Cross-resistance to telomestatin, a G-quadruplex ligand of a different series, could be observed in cells selected for their resistance to 12459 (Gomez et al. 2003b). These results provide evidence that telomerase and telomere length are key cellular determinants of the resistance to a G-quadruplex ligands. Other unrelated observations suggest that telomerase overexpression may modulate the apoptotic pathway and play a role in other resistance phenotypes as well $(\mathrm{Oh}$ et al. 2001). It is interesting to note that resistance of HCT116 human colon carcinoma cells to flavopiridol (a cyclin-dependent kinases inhibitor currently in phase II) was correlated with increases in hTERT expression and telomere length. Moreover, a treatment of flavopiridol-resistant cells with a quadruplex ligand (BRACO-19, as shown in Figure $3 \mathrm{~b}$ ) led to a rapid inhibition of cell growth, which could not be observed in the parental line (Incles et al. 2003).

\section{Conclusions}

There are several potential - or verified - problems with the anti-telomerase approach to the treatment of cancer. First, germ cells and many essential somatic cells do possess an active telomerase, and telomerase inhibitors are expected to act on these cells as well. Second, some tumor cells (up to 15\%) lack telomerase activity and can maintain telomeres through telomerase-independent mechanism (Bryan et al. 1995, 1997; Dunham et al. 2000; Hoare et al. 2001; Reddel 2003). Finally, telomerase-dependent cells would be expected to spontaneously become independent of telomerase if an anti-telomerase agent 
exerts a strong selection pressure. However, we did not observe such a conversion with G-quadruplex ligands: resistance occurred through an even higher expression of telomerase. According to the initial paradigm for telomerase inhibitors, these agents should not initially affect growth rate but should induce progressive telomere shortening and lead to decreased proliferation once telomeres have reached a critically short length. Accordingly, the time period needed to reach this critical point and produce anti-proliferative effects should depend on initial telomere length. This paradigm has been verified by several key experiments that were used for target validation purposes (Zhang et al. 1999). In some cases, this period might be too long to halt proliferation before the tumor reaches a life-threatening stage (Damm et al. 2001). Nevertheless, as shown above, recent experiments suggest that anti-telomere agents can also have immediate anti-proliferative effects, which may as well be selective towards the destruction of cancer cells.

Besides the specific problems discussed above, the development of anti-telomere and anti-telomerase agents will necessarily have to overcome the same standard obstacles as those faced by any new pharmacological agent and dictated by their pharmacokinetic properties, including cellular uptake and localization, binding to other intra- or extra-cellular components, biodistribution, metabolism, acute toxicity, half-life and so forth. Despite all of these potential pitfalls, it is likely that some telomerase inhibitors will soon be tested in humans. Clinical trials should provide a definitive answer to the feasibility of this approach.

\section{Acknowledgements}

This manuscript is dedicated to the memory of Professor Claude Hélène (1938-2003). This work was supported by ARC Grants (\#4321 and \#3365 to J.L.M. and \#4691 to J.F.R.) and an A.C.I. "Médicament et Cibles thérapeutiques" Grant from the Ministère de la Recherche et de la Technologie (to J.L.M., P.M., F.B. and J.F.R.). We wish to thank M. Ouellette for helpful suggestions and careful reading of this article.

\section{References}

Akiyama M., Hideshima T., Shammas M.A., Hayashi T., Hamasaki M., Tai Y.T., Richardson P., Gryaznov S., Munshi N.C. and Anderson K.C. 2003. Effects of oligonucleotide N3'- > P5' thio-phosphoramidate (GRN163) targeting telomerase RNA in human multiple myeloma cells. Cancer Res. 63: 6187-6194.

Alberti P., Hoarau M., Guittat L., Takasugi M., Arimondo P.B., Lacroix L., Mills M., Teulade-Fichou M.P., Vigneron J.P., Lehn J.M., Mailliet P. and Mergny J.L. 2002a. Triplex vs. Quadruplex specific ligands and telomerase inhibition. In: Wilson D. (ed.), Small Molecule DNA and RNA Binders: From Synthesis to Nucleic Acid Complexes. Wiley-VCH, Weinheim, pp.315-336.

Alberti P., Schmidt P., Nguyen C.H., Hoarau M., Grierson D. and Mergny J.L. 2002b. Benzoindoloquinolines interact with DNA quadruplexes and inhibit telomerase. Bioorg. Med. Chem. Lett. 12: 1071-1074.

Alberti P., Lacroix L., Guittat L., Hélène C. and Mergny J.L. 2003. Nucleic acids as targets for antitelomerase agents. Mini Rev. Med. Chem. 3: 23-36.

Asai A., Oshima Y., Yamamoto Y., Uochi T., Kusaka H., Akinaga S., Yamashita Y., Pongracz K., Pruzan R., Wunder E., Piatyszek M., Li S.H., Chin A.C., Harley C.B. and Gryaznov S. 2003. A novel telomerase template antagonist (GRN163) as a potential anticancer agent. Cancer Res. 63: 3931-3939.

Barma D.K., Elayadi A., Falck J.R. and Corey D.R. 2003. Inhibition of telomerase by BIBR 1532 and related analogues. Bioorg. Med. Chem. Lett. 13: 1333-1336.

Bodnar A.G., Ouellette M., Frolkis M., Holt S.E., Chiu C.P., Morin G.B., Harley C.B., Shay J.W., Lichtsteiner S. and Wright W.E. 1998. Extension of life-span by introduction of telomerase into normal human cells. Science 279: 349-352.

Brown T., Sigurdson E., Rogatko A. and Broccoli D. 2003. Telomerase inhibition using azidothymidine in the HT-29 colon cancer cell line. Ann. Surg. Oncol. 10: 910-915.

Bryan T.M., Englezou A., Gupta J., Bacchetti S. and Reddel R.R. 1995. Telomere elongation in immortal human cells without detectable telomerase activity. EMBO J. 14: 4240-4248.

Bryan T.M., Englezou A., Dalla Pozza L., Dunham M.A. and Reddel R.R. 1997. Evidence for an alternative mechanism for maintaining telomere length in human tumors and tumorderived cell lines. Nat. Med. 3: 1271-1274.

Caprio V., Guyen B., Opoku-Boahen Y., Mann J., Gowan S.M., Kelland L.M., Read M.A. and Neidle S. 2000. A novel inhibitor of human telomerase derived from $10 \mathrm{H}$-indolo[3,2b]quinoline. Bioorg. Med. Chem. Lett. 10: 2063-2066.

Chen Z., Koeneman K.S. and Corey D.R. 2003. Consequences of telomerase inhibition and combination treatments for the proliferation of cancer cells. Cancer Res. 63: 5917-5925.

Clark G.R., Pytel P.D., Squire C.J. and Neidle S. 2003. Structure of the first parallel DNA quadruplex-drug complex. J. Am. Chem. Soc. 125: 4066 4067.

Cocco M.J., Hanakahi L.A., Huber M.D. and Maizels N. 2003. Specific interactions of distamycin with G-quadruplex DNA. Nucleic Acids Res. 31: 2944-2951.

Colangelo D., Ghiglia A.L., Viano I., Cavigiolio G. and Osella D. 2003. Cis- $[\mathrm{Pt}(\mathrm{Cl})(2)($ Pyridine $)(5-\mathrm{SO} 3 \mathrm{H}$-isoquinoline $)]$ 
complex, a selective inhibitor of telomerase enzyme. Biometals 16: 553-560.

Cuesta J., Read M. and Neidle S. 2003. The design of Gquadruplex ligands as telomerase inhibitors. Mini Rev. Med. Chem. 3: 11-21.

Damm K., Hemmann U., Garin-Chesa P., Hauel N., Kauffmann I., Priepke H., Niestroj C., Daiber C., Enenkel B., Guilliard B., Lauritsch I., Müller E., Pascolo E., Sauter G., Pantic M., Martens U.M., Wenz C., Lingner J., Kraut N., Rettig W.J. and Schnapp A. 2001. A highly selective telomerase inhibitor limiting human cancer cell proliferation. EMBO J. 20: 6958-6968.

Darby R., Sollogoub M., McKeen C., Brown L., Risitano A., Brown N., Barton C., Brown T. and Fox K. 2002. High throughput measurement of duplex, triplex and quadruplex melting curves using molecular beacons and a Light Cycler. Nucleic Acids Res. 30: e39.

Didiano D., Shalaby T., Lang D. and Grotzer M. 2004. Telomere maintenance in childhood primitive neuroectodermal brain tumors. Neuro-Oncol. 6: 1-8.

Dunham M.A., Neumann A.A., Fasching C.L. and Reddel R.R. 2000. Telomere maintenance by recombination in human cells. Nat. Genet. 26: 447-450.

Elayadi A.N., Braasch D.A. and Corey D.R. 2002. Implications of high-affinity hybridization by locked nucleic acid oligomers for inhibition of human telomerase. Biochemistry 41 : 9973-9981.

Elayadi A.N., Demieville A., Wancewicz E.V., Monia B.P. and Corey D.R. 2001. Inhibition of telomerase by 2'-O-(2-methoxyethyl) RNA oligomers: effect of length, phosphorothioate substitution and time inside cells. Nucleic Acids Res. 29: 1683-1689.

Fedoroff O.Y., Salazar M., Han H., Chemeris V.V., Kerwin S.M. and Hurley L.H. 1998. NMR-based model of a telomerase inhibiting compound bound to G-quadruplex DNA. Biochemistry 37: 12367-12374.

Fletcher T.M., Cathers B.E., Ravikumar K.S., Mamiya B.M. and Kerwin S.M. 2001. Inhibition of human telomerase by 7deaza-2'-deoxyguanosine nucleoside triphosphate analogs: potent inhibition by 6-thio-7-deaza-2'-deoxyguanosine $5^{\prime}$ triphosphate. Bioorg. Chem. 29: 36-55.

Folini M., Berg K., Millo E., Villa R., Prasmickaite L., Daidone M.G., Benatti U. and Zaffaroni N. 2003. Photochemical internalization of a peptide nucleic acid targeting the catalytic subunit of human telomerase. Cancer Res. 63: 3490-3494.

Folini M., Colella G., Villa R., Lualdi S., Daidone M.G. and Zaffaroni N. 2000. Inhibition of telomerase activity by a hammerhead ribozyme targeting the RNA component of telomerase in human melanoma cells. J. Invest. Dermatol. 114: 259-267.

Francis R. and Friedman S.H. 2003. An interference-free fluorescent assay of telomerase for the high-throughput analysis of inhibitors. Anal. Biochem. 323: 65-73.

Furuta M., Nozawa K., Takemura M., Izuta S., Murate T., Tsuchiya M., Yoshida K., Taka N., Nimura Y. and Yoshida S. 2003. A novel platinum compound inhibits telomerase activity in vitro and reduces telomere length in a human hepatoma cell line. Int. J. Cancer 104: 709-715.

Gavathiotis E., Heald R.A., Stevens M.F.G. and Searle M.S 2001. Recognition and stabilization of quadruplex DNA by a potent new telomerase inhibitor: NMR studies of the $2: 1$ complex of a pentacyclic methylacridinium cation with d(TTAGGGT)(4). Angew. Chem. Int. Ed. Engl. 40:4749-4751.

Gavathiotis E., Heald R.A., Stevens M.F.G. and Searle M.S. 2003. Drug recognition and stabilisation of the parallelstranded DNA quadruplex d(TTAGGGT)(4) containing the human telomeric repeat. J. Mol. Biol. 334: 25-36.

Gomez D.E., Tejera A.M. and Olivero O.A. 1998. Irreversible telomere shortening by $3^{\prime}$-azido-2', $3^{\prime}$-dideoxythymidine (AZT) treatment. Biochem. Biophys. Res. Commun. 246: $107-110$.

Gomez D., Aouali N., Londono-Vallejo A., Lacroix L., Megnin-Chanet F., Lemarteleur T., Douarre C., Shinya K., Mailliet P., Trentesaux C., Morjani H., Mergny J.L. and Riou J.F. 2003a. Resistance to the short term antiproliferative activity of the G-quadruplex ligand 12459 is associated with telomerase overexpression and telomere capping alteration. J. Biol. Chem. 278: 50554-50562.

Gomez D., Aouali N., Renaud A., Douarre C., Shinya K., Tazi J., Martinez S., Trentesaux C., Morjani H. and Riou J.F. 2003b. Resistance to senescence induction and telomere shortening by a G-quadruplex ligand inhibitor of telomerase. Cancer Res. 63: 6149-6153.

Gomez D., Lemarteleur T., Lacroix L., Mailliet P., Mergny J.L. and Riou J.F. 2004a. Telomerase down regulation induced by the G-quadruplex ligand 12459 in A549 cells is mediated by hTERT RNA alternative splicing. Nucleic Acids Res. 32: 371-379.

Gomez D., Mergny J.L. and Riou J.F. 2002. Detection of telomerase inhibitors based on G-quadruplex ligands by a Modified Telomeric Repeat Amplification Protocol Assay. Cancer Res. 62: 3365-3368.

Gomez D., Paterski R., Lemarteleur T., Shin-ya K., Mergny J.L. and Riou J.F. 2004b. Interaction of telomestatin with the telomeric single-strand overhang. J. Biol. Chem. 279: 4148741494.

Gowan S.M., Harrison J.R., Patterson L., Valenti M., Read M.A., Neidle S. and Kelland L.R. 2002. A G-quadruplexinteractive potent small-molecule inhibitor of telomerase exhibiting in vitro and in vivo antitumor activity. Mol. Pharmacol. 61: 1154-1162.

Gowan S., Heald R., Stevens M. and Kelland L. 2001. Potent inhibition of telomerase by small-molecule pentacyclic acridines capable of interacting with G-quadruplexes. Mol. Pharmacol. 60: 981-988.

Greider C.W. and Blackburn E.H. 1985. Identification of a specific telomere terminal transferase activity in Tetrahymena extracts. Cell 43: 405-413.

Grimm J., Perez J.M., Josephson L. and Weissleder R. 2004. Novel nanosensors for rapid analysis of telomerase activity. Cancer Res. 64: 639-643.

Guyen B., Schultes C.M., Hazel P., Mann J. and Neidle S. 2004. Synthesis and evaluation of analogues of $10 \mathrm{H}$-indolo[3,2-b]-quinoline as G-quadruplex stabilising ligands and potential inhibitors of the enzyme telomerase. Org. Biomol. Chem. 2: 981-988.

Hahn W.C., Counter C.M., Lundberg A.S., Beijersbergen R.L., Brooks M.W. and Weinberg R.A. 1999a. Creation of human tumour cells with defined genetic elements. Nature 400: 464468.

Hahn W.C., Stewart S.A., Brooks M.W., York S.G., Eaton E., Kurachi A., Beijersbergen R.L., Knoll J.H.M., Meyerson M. 
and Weinberg R.A. 1999b. Inhibition of telomerase limits the growth of human cancer cells. Nat. Med. 5: 1164-1170.

Haider S.M., Parkinson G.N. and Neidle S. 2003. Structure of a G-quadruplex-ligand complex. J. Mol. Biol. 326: 117-125.

Hamilton S.E., Pitts A.E., Katipally R.R., Jia X.Y., Rutter J.P., Davies B.A., Shay J.W., Wright W.E. and Corey D.R. 1997. Identification of determinants for inhibitor binding within the RNA active site of human telomerase using PNA scanning. Biochemistry 36: 11873-11880.

Han H.Y., Hurley L.H. and Salazar M 1999. A DNA polymerase stop assay for G-quadruplex-interactive compounds. Nucleic Acids Res. 27: 537-542.

Hanahan D. and Weinberg R.A. 2000. The hallmarks of cancer. Cell 100: 57-70.

Haq I., Trent J.O., Chowdhry B.Z. and Jenkins T.C. 1999. Intercalative G-tetraplex stabilization of telomeric DNA by a cationic porphyrin. J. Am. Chem. Soc. 121: 1768-1779.

Harrison R.J., Cuesta J., Chessari G., Read M.A., Basra S.K., Reszka A.P., Morrell J., Gowan S.M., Incles C.M., Tanious F.A., Wilson W.D., Kelland L.R. and Neidle S. 2003. Trisubstituted acridine derivatives as potent and selective telomerase inhibitors. J. Med. Chem. 46: 4463-4476.

Harrison J.G., Frier C., Laurant R., Dennis R., Raney K.D. and Balasubramanian S. 1999a. Inhibition of human telomerase by PNA-cationic peptide conjugates. Bioorg. Med. Chem. Lett. 9: 1273-1278.

Harrison R.J., Gowan S.M., Kelland L.R. and Neidle S. 1999b. Human telomerase inhibition by substituted acridine derivatives. Bioorg. Med. Chem. Lett. 9: 2463-2468.

Hayakawa N., Nozawa K., Ogawa A., Kato N., Yoshida K., Akamatsu K., Tsuchiya M., Nagasaka A. and Yoshida S. 1999. Isothiazolone derivatives selectively inhibit telomerase from human and rat cancer cells in vitro. Biochemistry 38 : $11501-11507$.

Heald R.A., Modi C., Cookson J.C., Hutchinson I., Laughton C.A., Gowan S.M., Kelland L.R. and Stevens M.F.G. 2002. Antitumor polycyclic acridines. 8. Synthesis and telomeraseinhibitory activity of methylated pentacyclic acridinium salts. J. Med. Chem. 45: 590-597.

Herbert B.S., Pitts A.E., Baker S.I., Hamilton S.E., Wright W.E., Shay J.W. and Corey D.R. 1999. Inhibition of human telomerase in immortal human cells leads to progressive telomere shortening and cell death. Proc. Natl. Acad. Sci. USA 96: 14276-14281.

Hoare S.F., Bryce L.A., Wisman G.B.A., Burns S., Going J.J., van der Zee A.G.J. and Keith W.N. 2001. Lack of telomerase RNA gene hTERC expression in alternative lengthening of telomeres cells is associated with methylation of the hTERC promoter. Cancer Res. 61: 27-32.

Hud N.V., Smith F.W., Anet F.A.L. and Feigon J. 1996. The selectivity for $\mathrm{K}+$ versus $\mathrm{Na}+$ in DNA quadruplexes is dominated by relative free energies of hydration: a thermodynamic analysis by H-1 NMR. Biochemistry 35: 1538315390 .

Incles C.M., Schultes C.M., Kelland L.R. and Neidle S. 2003. Acquired cellular resistance to flavopiridol in a human colon carcinoma cell line involves up-regulation of the telomerase catalytic subunit and telomere elongation. Sensitivity of resistant cells to combination treatment with a telomerase inhibitor. Mol. Pharmacol. 64: 1101-1108.
Ishibashi T. and Lippard S.J. 1998. Telomere loss in cells treated with cisplatin. Proc. Natl. Acad. Sci. USA 95: 42194223.

Izbicka E., Nishioka D., Marcell V., Raymond E., Davidson K.K., Lawrence R.A., Wheelhouse R.T., Hurley L.H., Wu R.S. and Von Hoff D.D. 1999. Telomere-interactive agents affect proliferation rates and induce chromosomal destabilization in sea urchin embryos. Anticancer Drug Des. 14: 355365 .

Karlseder J., Smogorzewska A. and de Lange T. 2002. Senescence induced by altered telomere state, not telomere loss. Science 295: 2446-2449.

Keppler B.R. and Jarstfer M.B. 2004. Inhibition of telomerase activity by preventing proper assemblage. Biochemistry 43 : 334-343.

Kerwin S.M. 2000. G-quadruplex DNA as a target for drug design. Curr. Pharm. Design 6: 441-471.

Kim N.W., Piatyszek M.A., Prowse K.R., Harley C.B., West M.D., Ho P.L.C., Coviello G.M., Wright W.E., Weinrich S.L. and Shay J.W. 1994. Specific association of human telomerase activity with immortal cells and cancer. Science 266 : 2011-2015.

Kim M.Y., Vankayalapati H., Shin-Ya K., Wierzba K. and Hurley L.H. 2002. Telomestatin, a potent telomerase inhibitor that interacts quite specifically with the human telomeric intramolecular G-quadruplex. J. Am. Chem. Soc. 124: 2098 2099.

Kim N.W. and Wu F. 1997. Advances in quantification and characterization of telomerase activity by the telomeric repeat amplification protocol (TRAP). Nucleic Acids Res. 25: 25952597.

Kim J.H., Lee G.E., Kim S.W. and Chung I.K. 2003a. Identification of a quinoxaline derivative that is a potent telomerase inhibitor leading to cellular senescence of human cancer cells. Biochem. J. 373: 523-529.

Kim J.H., Lee G.E., Lee J.E. and Chung I.K. 2003b. Potent inhibition of human telomerase by nitrostyrene derivatives. Mol. Pharmacol. 63: 1117-1124.

Kim M.Y., Gleason Guzman M., Izbicka E., Nishioka D. and Hurley L.H. 2003c. The different biological effects of telomestatin and TMPyP4 can be attributed to their selectivity for interaction with intramolecular or intermolecular Gquadruplex structures. Cancer Res. 63: 3247-3256.

Koeppel F., Riou J.F., Laoui A., Mailliet P., Arimondo P.B., Labit D., Petigenet O., Hélène C. and Mergny J.L. 2001. Ethidium derivatives bind to G-quartets, inhibit telomerase and act as fluorescent probes for quadruplexes. Nucleic Acids Res. 29: 1087-1096.

Koga S., Kondo Y., Komata T. and Kondo S. 2001. Treatment of bladder cancer cells in vitro and in vivo with $2-5 \mathrm{~A}$ antisense telomerase RNA. Gene Therapy 8: 654-658.

Kondo S., Kondo Y., Li G., Silverman R.H. and Cowell J.K. 1998. Targeted therapy of human malignant glioma in a mouse model by $2-5 \mathrm{~A}$ antisense directed against telomerase RNA. Oncogene 16: 3323-3330.

Kosciolek B.A., Kalantidis K., Tabler M. and Rowley P.T. 2003. Inhibition of telomerase activity in human cancer cells by RNA interference. Mol. Cancer Ther. 2: 209-216.

Kraemer K., Fuessel S., Schmidt U., Kotzsch M., Schwenzer B., Wirth M. and Meye A. 2003. Antisense-mediated hTERT 
inhibition specifically reduces the growth of human bladder cancer cells. Clin. Cancer Res. 9: 3794-3800.

Kuranaga N., Shinomiya N. and Mochizuki H. 2001. Longterm cultivation of colorectal carcinoma cells with anti-cancer drugs induces drug resistance and telomere elongation: an in vitro study. BMC Cancer 1: 10.

Li W., Miyoshi D., Nakano S. and Sugimoto N. 2003. Structural competition involving G-quadruplex DNA and its complement. Biochemistry 42: 11736-11744.

Maeshima K., Janssen S. and Laemmli U.K. 2001. Specific targeting of insect and vertebrate telomeres with pyrrole and imidazole polyamides. EMBO J. 20: 3218-3228.

Maraval A., Franco S., Vialas C., Pratviel G., Blasco M.A. and Meunier B. 2003. Porphyrin-aminoquinoline conjugates as telomerase inhibitors. Org. Biomol. Chem. 1: 921-927.

Masutomi K., Yu E.Y., Khurts S., BenPorath I., Currier J.L., Metz G.B., Brooks M.W., Kaneko S., Murakami S., DeCaprio J.A., Weinberg R.A., Stewart S.A. and Hahn W.C. 2003. Telomerase maintains telomere structure in normal human cells. Cell 114: 241-253.

Mergny J.L., Lacroix L., Teulade-Fichou M.P., Hounsou C., Guittat L., Hoarau M., Arimondo P.B., Vigneron J.P., Lehn J.M., Riou J.F., Garestier T. and Hélène C. 2001. Telomerase inhibitors based on quadruplex ligands selected by a fluorescent assay. Proc. Natl. Acad. Sci. USA 98: 3062-3067.

Mergny J.L., Riou J.F., Mailliet P., Teulade-Fichou M.P. and Gilson E. 2002. Natural and pharmacological regulation of telomerase. Nucleic Acids Res. 30: 839-865.

Meyerson M., Counter C.M., Eaton E.N., Ellisen L.W., Steiner P., Caddle S.D., Ziaugra L., Beijersbergen R.L., Davidoff M.J., Liu Q.Y., Bacchetti S., Haber D.A. and Weinberg R.A. 1997. hEST2, the putative human telomerase catalytic subunit gene, is up-regulated in tumor cells and during immortalization. Cell 90: 785-795.

Miyoshi D., Matsumura S., Nakano S. and Sugimoto N. 2004. Duplex dissociation of telomere DNAs induced by molecular crowding. J. Am. Chem. Soc. 126: 165-169.

Mukai S., Kondo Y., Koga S., Komata T., Barna B.P. and Kondo S. 2000. 2-5A antisense telomerase RNA therapy for intracranial malignant gliomas. Cancer Res. 60: 4461-4467.

Multani A.S., Furlong C. and Pathak S. 1998. Reduction of telomeric signals in murine melanoma and human breast cancer cell lines treated with $3^{\prime}$-azido-2'-3'-dideoxythymidine. Int. J. Oncol. 13: 923-925.

Naasani I., Ohhashi F., Ohhara T., Feng W.Y., Johnston J., Chan K. and Tsuruo T. 2003. Blocking telomerase by dietary polyphenols is a major mechanism for limiting the growth of human cancer cells in vitro and in vivo. Cancer Res. 63: 824830 .

Naasani I., Seimiya H. and Tsuruo T. 1998. Telomerase inhibition, telomere shortening and senescence of cancer cells by tea catechins. Biochem. Biophys. Res. Commun. 249: 391396.

Nakajima A., Tauchi T., Sashida G., Sumi M., Abe K., Yamamoto K., Ohyashiki J.H. and Ohyashiki K. 2003. Telomerase inhibition enhances apoptosis in human acute leukemia cells: possibility of antitelomerase therapy. Leukemia 17: $560-567$.

Neidle S., Harrison R.J., Reszka A.P. and Read M.A. 2000. Structure-activity relationships among guanine-quadruplex telomerase inhibitors. Pharmacol. Ther. 85: 133-139.
Neidle S. and Parkinson G.N. 2003. The structure of telomeric DNA. Curr. Opin. Struct. Biol. 13: 275-283.

Norton J.C., Piatyszek M.A., Wright W.E., Shay J.W. and Corey D.R. 1996. Inhibition of human telomerase activity by peptide nucleic acids. Nat. Biotechnol. 14: 615-619.

Oh H., Taffet G.E., Youker K.A., Entman M.L., Overbeek P.A., Michael L.H. and Schneider M.D. 2001. Telomerase reverse transcriptase promotes cardiac muscle cell proliferation, hypertrophy, and survival. Proc. Natl. Acad. Sci. USA 98: 10308-10313.

Parkinson G.N., Lee M.P.H. and Neidle S. 2002. Crystal structure of parallel quadruplexes from human telomeric DNA. Nature 417: 876-880.

Pascolo E., Wenz C., Lingner J., Hauel N., Priepke H., Kauffmann I., GarinChesa P., Rettig W.J., Damm K. and Schnapp A. 2002. Mechanism of human telomerase inhibition by BIBR1532, a synthetic, non-nucleosidic drug candidate. J. Biol. Chem. 277: 15566-15572.

Perry P.J., Read M.A., Davies R.T., Gowan S.M., Reszka A.P., Wood A.A., Kelland L.R. and Neidle S. 1999. 2,7-disubstituted amidofluorenone derivatives as inhibitors of human telomerase. J. Med. Chem. 42: 2679-2684.

Phan A.T. and Mergny J.L. 2002. Human telomeric DNA: Gquadruplex, i-motif and Watson-Crick double helix. Nucleic Acids Res. 30: 4618-4625.

Phan A.T. and Patel D.J. 2003. Two-repeat human telomeric d(TAGGGTTAGGGT) sequence forms interconverting parallel and antiparallel G-quadruplexes in solution: distinct topologies, thermodynamic properties, and folding/unfolding kinetics. J. Am. Chem. Soc. 125: 15021-15027.

Pitts A.E. and Corey D.R. 1998. Inhibition of human telomerase by $2^{\prime}-O$-methyl-RNA. Proc. Natl. Acad. Sci. USA 95: $11549-11554$.

Pruzan R., Pongracz K., Gietzen K., Wallweber G. and Gryaznov S. 2002. Allosteric inhibitors of telomerase: oligonucleotide N3 '- > P5 'phosphoramidates. Nucleic Acids Res. 30: $559-568$.

Read M., Harrison R.J., Romagnoli B., Tanious F.A., Gowan S.H., Reszka A.P., Wilson W.D., Kelland L.R. and Neidle S. 2001. Structure-based design of selective and potent G quadruplex-mediated telomerase inhibitors. Proc. Natl. Acad. Sci. USA 98: 4844-4849.

Read M. and Neidle S. 2000. Structural characterization of a guanine-quadruplex ligand complex. Biochemistry 39: 13422 13432.

Reddel R.R. 2003. Alternative lengthening of telomeres, telomerase, and cancer. Cancer Lett. 194: 155-162.

Rezler E.M., Bearss D.J. and Hurley L.H. 2003. Telomere inhibition and telomere disruption as processes for drug targeting. Annu. Rev. Pharmacol. Toxicol. 43: 359-379.

Riou J.F., Guittat L., Renou E., Mailliet P., Laoui A., Petigenet O., Hélène C. and Mergny J.L. 2002. Cell senescence and telomere shortening induced by a new series of specific quadruplex DNA ligands. Proc. Natl. Acad. Sci. USA 99: 2672-2677.

Rossetti L., Franceschin M., Bianco A., Ortaggi G. and Savino M. 2002. Perylene diimides with different side chains are selective in inducing different G-quadruplex DNA structures and in inhibiting telomerase. Bioorg. Med Chem. Lett. 12: $2527-2533$. 
Saretzki G. 2003. Telomerase inhibition as cancer therapy. Cancer Lett. 194: 209-219.

Saretzki G., Ludwig A., von Zglinicki T. and Runnebaum I.B. 2001. Ribozyme-mediated telomerase inhibition induces immediate cell loss but not telomere shortening in ovarian cancer cells. Cancer Gene Ther. 8: 827-834.

Sasaki S., Ehara T., Sakata I., Fujino Y., Harada N., Kimura J., Nakamura H. and Maeda M. 2001. Development of novel telomerase inhibitors based on a bisindole unit. Bioorg. Med. Chem. Lett. 11: 583-585.

Schindler A., Fiedler U., Meye A., Schmidt U., Fussel S., Pilarsky C., Herrmann J. and Wirth M.P. 2001. Human telomerase reverse transcriptase antisense treatment downregulates the viability of prostate cancer cells in vitro. Int. J. Oncol. 19: 25-30.

Schouten J.A., Ladame S., Mason S.J., Cooper M.A. and Balasubramanian S. 2003. G-quadruplex-specific peptidehemicyanine ligands by partial combinatorial selection. J. Am. Chem. Soc. 125: 5594-5595.

Seimiya H., Ohhara T., Suzuki T., Naasani I., Shimazaki T., Tsuchiya K. and Tsuruo T. 2002. Telomere shortening and growth inhibition of human cancer cells by novel synthetic telomerase inhibitors MST-312, MST-295, and MST-199. Mol. Cancer Ther. 1: 657-665.

Shammas M., Liu X., Gavory G., Raney K., Balasubramanian S. and Shmookler-Reis R. 2004. Targeting the single-strand G-rich overhang of telomeres with PNA inhibits cell growth and induces apoptosis of human immortal cells. Exp. Cell Res. 295: 204-214.

Shammas M.A., Reis R.J.S., Akiyama M., Koley H., Chauhan D., Hideshima T., Goyal R.K., Hurley L.H., Anderson K.C. and Munshi N.C. 2003. Telomerase inhibition and cell growth arrest by G-quadruplex interactive agent in multiple myeloma. Mol. Cancer Ther. 2: 825-833.

Shammas M.A., Simmons C.G., Corey D.R. and Reis R.J.S. 1999. Telomerase inhibition by peptide nucleic acids reverses 'immortality' of transformed human cells. Oncogene 18: 6191-6200.

Shi D.F., Wheelhouse R.T., Sun D.Y. and Hurley L.H. 2001. Quadruplex-interactive agents as telomerase inhibitors: Synthesis of porphyrins and structure-activity relationship for the inhibition of telomerase. J. Med. Chem. 44: 4509-4523.

Stewart S.A., BenPorath I., Carey V.J., OConnor B.F., Hahn W.C. and Weinberg R.A. 2003. Erosion of the telomeric single-strand overhang at replicative senescence. Nat. Genet. 33: 492-496.

Strahl C. and Blackburn E.H. 1994. The effects of nucleoside analogs on telomerase and telomeres in tetrahymena. Nucleic Acids Res. 22: 893-900.

Strahl C. and Blackburn E.H. 1996. Effects of reverse transcriptase inhibitors on telomere length and telomerase activity in two immortalized human cell lines. Mol. Cell. Biol. 16: 5365.

Sun D., Thompson B., Cathers B.E., Salazar M., Kerwin S.M., Trent J.O., Jenkins T.C., Neidle S. and Hurley L.H. 1997. Inhibition of human telomerase by a G-quadruplex-interactive compound. J. Med. Chem. 40: 2113-2116.

Takahashi R., Bando T. and Sugiyama H. 2003. Specific alkylation of human telomere repeats by hairpin pyrroleimidazole polyamide. Bioorg. Med. Chem. 11: 2503-2509.
Tauchi T., Shinya K., Sashida G., Sumi M., Nakajima A., Shimamoto T., Ohyashiki J.H. and Ohyashiki K. 2003. Activity of a novel G-quadruplex-interactive telomerase inhibitor, telomestatin (SOT-095), against human leukemia cells: involvement of ATM-dependent DNA damage response pathways. Oncogene 22: 5338-5347.

Teng L.S., Specht M.C., Barden C.B. and Fahey T.J. 2003. Antisense hTERT inhibits thyroid cancer cell growth. J. Clin. Endocrinol. Metab. 88: 1362-1366.

Villa R., Folini M., Lualdi S., Veronese S., Daidone M.G. and Zaffaroni N. 2000. Inhibition of telomerase activity by a cellpenetrating peptide nucleic acid construct in human melanoma cells. FEBS Lett. 473: 241-248.

Wang Y. and Patel D.J. 1993. Solution structure of the human telomeric repeat d[AG3(T2AG3)3] G-Tetraplex. Structure 1: 263-282.

Wang E.S., Wu K.D., Chin A.C., ChenKiang S., Pongracz K., Gryaznov S. and Moore M.A.S. 2004. Telomerase inhibition with an oligonucleotide telomerase template antagonist: in vitro and in vivo studies in multiple myeloma and lymphoma. Blood 103: 258-266.

Wheelhouse R.T., Sun D., Han H., Han F.X. and Hurley L.H. 1998. Cationic porphyrins as telomerase inhibitors: the interaction of tetra ( $N$-methyl-4-pyridyl) porphyrin with quadruplex DNA. J. Am. Chem. Soc. 120: 3261-3262.

White L.K., Wright W.E. and Shay J.W. 2001. Telomerase inhibitors. Trends Biotech. 19: 114-120.

Whitney A.M., Ladame S. and Balasubramanian S. 2004. Templated ligand assembly by using G-quadruplex DNA and dynamic covalent chemistry. Angew. Chem. Int. Ed. Engl. 43: $1143-1146$.

Williamson J.R. 1994. G-quartet structures in telomeric DNA. Annu. Rev. Biophys. Biomol. Struct. 23: 703-730.

Williamson J.R., Raghuraman M.K. and Cech T.R. 1989. Monovalent cation induced structure of telomeric DNA: the G-quartet model. Cell 59: 871-880.

Yatabe N., Kyo S., Kondo S., Kanaya T., Wang Z., Maida Y., Takakura M., Nakamura M., Tanaka M. and Inoue M. 2002. 2-5A antisense therapy directed against human telomerase RNA inhibits telomerase activity and induces apoptosis without telomere impairment in cervical cancer cells. Cancer Gene Ther. 9: 624-630.

Yegorov Y.E., Chernov D.N., Akimov S.S., Bolsheva N.L., Krayevsky A.A. and Zelenin A.V. 1996. Reverse transcriptase inhibitors suppress telomerase function and induce senescence-like processes in cultured mouse fibroblasts. FEBS Lett. 389: 115-118.

Yokoyama Y., Takahashi Y., Shinohara A., Lian Z.L., Wan X.Y., Niwa K. and Tamaya T. 1998. Attenuation of telomerase activity by a hammerhead ribozyme targeting the template region of telomerase RNA in endometrial carcinoma cells. Cancer Res. 58: 5406-5410.

Yokoyama Y., Takahashi Y., Shinohara A., Wan X.Y., Takahashi S., Niwa K. and Tamaya T. 2000. The $5^{\prime}$-end of hTERT mRNA is a good target for hammerhead ribozyme to suppress telomerase activity. Biochem. Biophys. Res. Commun. 273: 316-321

Yokoyama Y., Wan X., Takahashi Y., Shinohara A., Liulin T. and Tamaya T. 2002. Divalent hammerhead ribozyme targeting template region of human telomerase RNA has potent 
cleavage activity, but less inhibitory activity on telomerase. Arch. Biochem. Biophys. 405: 32-37.

Yokoyama M., Noguchi M., Nakao Y., Pater A. and Iwasaka T. 2004. The tea polyphenol, (-)-epigallocatechin gallate effects on growth, apoptosis, and telomerase activity in cervical cell lines. Gynecol. Oncol. 92: 197-204.

Zahler A.M., Williamson J.R., Cech T.R. and Prescott D.M. 1991. Inhibition of telomerase by G-quartet DNA structures. Nature 350: 718-720.
Zhang X.L., Mar V., Zhou W., Harrington L. and Robinson M.O. 1999. Telomere shortening and apoptosis in telomerase-inhibited human tumor cells. Genes Dev. 13: 2388-2399.

Zhu X.D., Niedernhofer L., Kuster B., Mann M., Hoeijmakers J.H. and de Lange T. 2003. ERCC1/XPF removes the $3^{\prime}$ overhang from uncapped telomeres and represses formation of telomeric DNA-containing double minute chromosomes. Mol. Cell 12: 1489-1498. 